ALEKSANDRA RzEPKOWSKA

Uniwersytet Mikołaja Kopernika w Toruniu

Katedra Etnologii i Antropologii Kulturowej

\title{
W MIEŚCIE I NA WSI. \\ O DOŚWIADCZANIU PRZESTRZENI W AUTYZMIE - REKONESANS ANTROPOLOGICZNY
}

\section{Zamiast wstępu - życie w kręgu autyzmu}

Uekst mój jest częścią większego projektu badawczego dedykowanego doświadczeniu autyzmu. Jego realizacja w dużym stopniu

1 wyrasta z przyczyn osobistych. Z osobami autystycznymi mam bowiem do czynienia od dawna. Wiem także, jak trudne jest codzienne funkcjonowanie z tym zaburzeniem - zarówno dla tych, którzy zostali nim dotknięci, jak i dla ich bliskich. Cierpiący na autyzm muszą zmagać się z nietolerancją i niezrozumieniem otoczenia, poczuciem społecznej nieprzynależności, ponieważ środowiska, do udziału w których aspirują, często ich piętnują i odrzucają. Niełatwy jest też los ich bliskich. Przede wszystkim muszą odpowiedzieć sobie na pytanie, skąd bierze się odmienność ich krewnych przyjaciół lub znajomych, a to nie zawsze jest proste. Nie każdy ma szczęście spotkać na swej drodze doświadczonego lekarza czy terapeutę, który w porę rozpozna tę dysfunkcję, objaśni jej zawiłości, udzieli psychologicznego wsparcia oraz zaordynuje właściwe leczenie. Zresztą samo przyjęcie diagnozy również jest wyzwaniem. Ciężko pogodzić się ze świadomością, że bliska nam osoba jest chora, wymaga żmudnej i wieloletniej terapii, która jednak nie daje szans na całkowite wyzdrowienie, lecz najwyżej na wyciszenie lub złagodzenie niektórych objawów. Czasem odrzuca się tę gorzką prawdę, zaprzecza rzeczywistości udając, że wszystko jest w porządku, że to, co niepokojące i złe samo przejdzie. Równie istotnym problemem jest 
codzienne życie z osobą autystyczną, akceptacja jej specyficznych reakcji, rytuałów i zachowań. Życie w bezpośrednim kręgu autyzmu, sprawowanie opieki nad człowiekiem z tym zaburzeniem bywają nadzwyczaj stresujące, mogą prowadzić do poważnych kryzysów i załamań psychicznych. I wreszcie, podobnie jak sami autyści ${ }^{1}$, także ich bliscy muszą radzić sobie z nieprzychylnym często nastawieniem otoczenia - znosić złośliwości czy przytyki pod swoim adresem. Tym bardziej że mur niezrozumienia i niechęci okazuje się w wielu przypadkach nie do przebicia. Fizjonomia autystów nie odbiega od społecznie przyjętej normy, nie wyróżniają ich żadne cielesne deformacje czy kulturowe atrybuty choroby - ci ludzie nie jeżdżą na wózkach, nie kuśtykają o kulach, nie noszą protez ortopedycznych oraz masywnych szkieł, a jeśli nawet, to nie z powodu autyzmu. Co więcej, wiele autystycznych dzieci wyróżnia się podobno nieskazitelną powierzchownością i urodą. A skoro tak - ten typ myślenia (jakże naiwny i krzywdzący) przeważa u osób postronnych - to znaczy, że ich niestandardowe zachowanie nie jest skutkiem zaburzenia rozwojowego, lecz zaniedbań wychowawczych i błędów rodziny, która nie dopilnowała, nie wychowała, wypuściła w świat nieznośnego dziwaka, niezdarę i odmieńca. Niekiedy zdarza się, że rodzina - w obawie przed różnymi formami społecznej dewaluacji i dyskryminacji nie ujawnia faktu, że bliski cierpi na autyzm. Zamykanie się w - narosłej na podłożu lęku czy wstydu - skorupie wyparcia i milczenia ma jednak swoje negatywne, a czasem wręcz dramatyczne konsekwencje psychiczne oraz biograficzne.

Mam nadzieję, że moje opracowanie przyczyni się w jakimś - choćby najskromniejszym wymiarze - do poszerzenia ogólnej wiedzy o autyzmie, a tym samym do otwarcia się na ten problem i ludzi nim dotkniętych. Daleka jestem od zamiaru mitologizacji czy uromantyczniania tej przypadłości. Zdaję sobie sprawę, że ma ona zarówno jasną, jak i mroczną stronę. Autyzm wiąże się niekiedy z aurą niezwykłości, bogactwem intelektu i wyobraźni, oprócz tego jednak przynosi ból i cierpienie - zarówno samym chorym, jak i ich bliskim. Mój tekst nie jest przeto aktem apoteozy tego zaburzenia, lecz próbą zrozumienia tej formy inności, oswajania z nią oraz budzenia szacunku dla niej.

1 Najnowsze słowniki jako poprawne podają formy „autyk” oraz „autysta”. Pierwsza z nich znajduje dość dobre oparcie w analogicznych przykładach („astygmatyzm - astygmatyk”, „reumatyzm - reumatyk"), jednak ta druga wydaje mi się zręczniejsza, dlatego posługuję się w nią w swych rozważaniach. 


\section{Narracje autobiograficzne jako jeden z kluczy do poznania antropologicznego}

Podstawowym celem współczesnej, hermeneutycznie uwrażliwionej antropologii jest próba zrozumienia człowieka w jego świecie - osadzonym w konkretnym czasie i przestrzeni. Szczególnie pomocne w realizacji tego zadania są narracje autobiograficzne ${ }^{2}$, zarówno te pisane, jak i ustne. Są one bowiem jednym z najważniejszych miejsc, w których ludzka egzystencja wyraża się i ujawnia w sposób możliwie zniuansowany i wielostronny. Wsłuchiwanie się w tego rodzaju wypowiedzi, a także ich skupiona i zaangażowana lektura pozwalają rozpoznać sposoby, w jakie ludzie przeżywają swoje uczestnictwo w świecie kultury; dają wgląd w tworzone przez nich hierarchie istotności i ważności, wyznawane poglądy i wartości, doznawane emocje i uczucia. Oczywiście nie każda wypowiedź językowa jest narracją. Możemy o niej mówić zwłaszcza wtedy, gdy wypowiedź taka zyskuje strukturę sekwencyjną, z wyraźnie zaznaczonym początkiem, środkiem oraz zakończeniem, a także jeśli informuje ona o przebiegu określonych zdarzeń, o zachowaniach, intencjach, celach oraz odczuciach ich uczestników ${ }^{3}$. Tak pojęte narracje osobiste stanowią ważny materiał empiryczny, po który sięgają badacze - biografiści w swoich eksploracjach i projektach naukowych. Ze względu na swe cechy: obszerność, rozlewność, refleksyjność, a nierzadko także wielotematyczność i wielowątkowość są one szczególnie chętnie, a ostatnio również o wiele częściej niż inne materiały, wykorzystywane w obszarze badań i analiz o nachyleniu biograficznym. W badaniach tych, w zależności od ich specyfiki, a także przyjmowanych celów, tez i założeń, sięga się po opowieści mówione, spisane albo - co także się zdarza - po obie ich odmiany. W swoim opracowaniu wykorzystuję te drugie, dlatego pozwolę sobie omówić pokrótce ich specyfikę.

${ }^{2}$ Ludzka pamięć jest przede wszystkim działaniem komunikacyjnym, dlatego określeń takich, jak: „narracja autobiograficzna” oraz „autobiografia” używam w tym artykule wymiennie. Ze względów stylistycznych, aby uniknąć natrętnego powtarzania tego samego słowa, określenia te zastępuję czasami terminami bliskoznacznymi, jak choćby „relacja” czy „opowieść”.

${ }^{3}$ P. Ricoeur, Czas i opowieść. Konfiguracja w opowieści fikcyjnej, t. 2, tłum. J. Jakubowski, Wydawnictwo Uniwersytetu Jagiellońskiego, Kraków 2008, s. 9. Nie znaczy to, oczywiście, że narracja wyraża ostateczną i definitywną prawdę o życiu jej autora. Jest to niemożliwe choćby dlatego, że ludzka tożsamość nie stanowi jakiegoś nieruchomego i zamkniętego tworu, zawierającego pełnię samowiedzy jednostki, lecz jest dynamiczna i zmienna, nasyca się nowymi treściami wraz z upływem czasu oraz gromadzeniem kolejnych doświadczeń życiowych przez jednostkę. Z tego powodu badacze - narratywiści ujmują ją zawsze czasowo i historycznie. 
Zacznę od tego, iż autorami analizowanych przeze mnie wypowiedzi są osoby autystyczne, zarazem zaś bardzo inteligentne i uzdolnione. Żadna $\mathrm{z}$ nich nie jest jednak zawodowym pisarzem, stąd w proces powstania ich tekstów były włączone osoby trzecie, zajmujące się profesjonalnie słowem. Osoby te w pewnej mierze ingerowały w strukturę tych relacji, dokonywały korekty stylistycznej oraz redakcji poszczególnych partii opowieści. Niemniej jednak przekazy te zostały utworzone na kanwie doświadczeń autystów, są formułowane w pierwszej osobie liczby pojedynczej oraz sygnowane ich nazwiskami, co pozwala mi traktować je jak autobiografie, w znaczeniu, jakie nadał temu pojęciu francuski badacz - Philippe Lejeune. Zgodnie z opracowaną przez niego koncepcją każda autobiografia opiera się na tak zwanym pakcie autobiograficznym, czyli swoistej umowie pomiędzy autorem a czytelnikiem, zakładającej tożsamość trzech głównych instancji nadawczych tekstu, a więc autora, narratora i głównego bohatera ${ }^{4}$.

Pakt autobiograficzny - przekonuje Ph. Lejeune - to poważna sprawa. Osadza on tekst w rzeczywistości stosunków z innymi, pozwala wnętrzu współgrać z zewnętrzem, temu, co intymne, z tym, co społeczne, opiera się na pojęciu prawdomówności (świadectwa), uwydatnia prawa i obowiązki. Podmiot indywidualny nie jest iluzją, lecz kruchą realnością 5 .

Cechą definicyjną autobiografii jest zatem deklaracja, ogłoszenie owej tożsamości przez autora. Może się to odbyć zarówno pośrednio, poprzez użycie tytułu zawierającego wyraźną autobiograficzną sugestię, jak choćby Dzieje mojego życia, Historia mojego życia, Opowieść o moich losach ${ }^{6}$ itp., poprzez przedstawienie takiego zobowiązania na początku tekstu albo bezpośrednio - poprzez nadanie głównemu bohaterowi własnego imienia i nazwiska ${ }^{7}$.

${ }^{4}$ Systematyczny wykład tej koncepcji znajduje się w pracy Ph. Lejeune’a poświęconej autobiografii. Tenże, Wariacje na temat pewnego paktu. O autobiografii, tłum. W. Grajewski, S. Jaworski, A. Labuda, R. Lubas-Bartoszyńska, Towarzystwo Autorów i Wydawców Prac Naukowych UNIVERSITAS, Kraków 2001.

${ }^{5}$ Tamże, s. 285.

${ }^{6}$ Opowiadając o sobie, o swoim życiu korzystamy jednak, choć nie zawsze świadomie i intencjonalnie, z cudzej wiedzy i cudzych przekazów na ten temat. Ludzka pamięć jest bowiem dialogowa, kształtuje się zawsze w interakcji ze światem zewnętrznym, z innymi ludźmi i tekstami kultury.

${ }^{7}$ W świetle przedstawionej koncepcji nie jest więc ważne, czy autor całkiem sam, bez niczyjej pomocy spisał dzieje swojego życia, ale to, czy się z tym przekazem identyfikuje, czy rozpoznaje w nim siebie samego i swoją biografię. 
Dla Ph. Lejeune'a nie jest także istotne, czy tekst autobiografii mówi prawdę o życiu autora, ale czy niesie w sobie taki zamiar i intencję. Obok paktu autobiograficznego pojawia się bowiem u francuskiego myśliciela również kategoria paktu referencjalnego, rozumianego jako moralna obietnica, a nawet więcej - przysięga mówienia prawdy, jaką autor składa czytelnikowi, przy czym prawda jest tu rozumiana w kategoriach prawdy narracyjnej, a nie prawdy faktów. Z uwagi na ograniczenia języka oraz ludzkiej pamięci (subiektywnej, ulotnej, zawodnej, kreacyjnej, imaginacyjnej) nikt nie jest wszak zdolny dokonać wiernego odtworzenia własnego życia, może jedynie próbować przedstawić jego aktualne wyobrażenie ${ }^{8}$. Czasami mamy ponadto do czynienia $\mathrm{z}$ intencjonalnym retuszowaniem i upiększaniem własnej autobiografii, co może wynikać z potrzeby pozytywnej autoprezentacji, zachowania twarzy. Nie burzy to jednak fundamentalnego sensu całego przedsięwzięcia, albowiem - jak wyjaśnia narratywista -

(...) w autobiografii ścisłość nie jest kwestią najważniejszą. W autobiografii jest (...) niezbędne, by pakt referencjalny został zawarty i dotrzymany, lecz rezultat nie wymaga oceny w kategoriach ścisłego podobieństwa. W świetle czytelniczych kryteriów pakt ten może być dotrzymany niedobrze i nie przekreśla to referencjalnej wartości autobiografii (przeciwnie), jak to ma miejsce w wypadku tekstów historycznych i dziennikarskich?

O specyfice podejścia Ph. Lejeune’a do autobiografii stanowi również to, że jest ona dlań zarówno przedmiotem wiedzy, jak i wiary oraz istnieje o tyle, o ile istnieją ci, którzy w nią wierzą i jej pragną, ponieważ nie są dostępne w pełni skuteczne techniki weryfikacyjne, które mogłyby w sposób precyzyjny i rzetelny zmierzyć poziom autentyczności tekstu (w znaczeniu prawdy korespondencyjnej) - to, na ile dokładnie i ciasno przylega on do faktów (któż zresztą miałby to orzekać i rozstrzygać?). Autobiografia istnieje zatem w tej mierze, w jakiej „(...) prawda autobiograficzna realnie działa w przestrzeni ludzkiej komunikacji"10. Wypowiedzi autobiograficzne nie są więc

${ }^{8}$ Warto w tym miejscu zaznaczyć, iż w autyzmie, który stanowi główny przedmiot mojego zainteresowania, może występować pewien szczególny typ pamięci, cechującej się tendencjami do hiperszczegółowości oraz wiernego reprodukowania treści doświadczenia. Czasem mówi się o niej jako o pamięci podobnej - w swym zafiksowaniu na oryginalnym wydarzeniu - do zapisu komputerowego.

${ }_{9}$ Ph. Lejeune, dz. cyt., s. 47-48.

${ }_{10}$ P. Rodak, Wstęp. Autobiografia i dziennik osobisty jako przedmiot badań Philippe'a Lejeune'a, [w:] Ph. Lejeune, „Drogi zeszycie...”, „drogi ekranie..... O dziennikach osobistych, tłum. A. Karpowicz, M. i P. Rodakowie, Wydawnictwo Uniwersytetu Warszawskiego, Warszawa 2010, s. 16. 
dla francuskiego uczonego jedynie obiektami estetycznej konsumpcji czy kontemplacji, lecz są przede wszystkim środkami społecznego porozumienia się i społecznej wymiany, za których pomocą możemy się nawzajem zbliżać, komunikować i rozumiećc ${ }^{11}$. Dlatego też tak doniosła jest dlań wywiedziona z pragmatyki i filozofii Paula Ricoeura - kategoria tożsamości narracyjnej, odnosząca się do wyobrażenia podmiotu o samym sobie, które to wyobrażenie podmiot ujawnia i udostępnia innym $\mathrm{w}$ formie autonarracji ${ }^{12}$. Oto, co Ph. Lejeune pisze na ten temat:

Jeśli chodzi o fakt, że tożsamość indywidualna, zarówno w piśmiennictwie, jak i w życiu, tworzy się dzięki opowiadaniu, to nie znaczy to bynajmniej, że mieści się ona w świecie fikcji. (...) Jeśli tożsamość jest wyobrażeniem, autobiografia przylegająca do tego wyobrażenia mieści się po stronie prawdy. I nie ma nic wspólnego z zamierzoną grą fikcji ${ }^{13}$.

W przywołanym cytacie dochodzi do głosu - silnie podkreślane przez P. Ricoeura - przekonanie o nietożsamości życia i opowieści. Zgodnie z jego stanowiskiem pomiędzy tymi realnościami istnieje wielka różnica, stąd „Logika działania, aby stała się logiką narracji, musi zwrócić się ku rozpoznanym kulturowym konfiguracjom, ku schematom przebiegu konstytuowanym przez typy plotu przekazane przez tradycję"14. Narracja to zatem dla P. Ricoeura kody tekstowe, wytworzone przez kulturę, po które sięgamy, by nadać formę, uporządkować i zrozumieć nasze doświadczenie. Jest to zresztą jedna z osi sporu i dyskusji pomiędzy P. Ricoeurem a innymi narratywistami, którzy przypisują strukturę narracyjną już samym procesom myślenia, pojmowania oraz interpretacji ${ }^{15}$. W dyskusji tej opowiadam się za

${ }^{11} \mathrm{Z}$ tego powodu Ph. Lejeune, w przeciwieństwie do badaczy o nastawieniu literaturocentrycznym, rozciąga obszar swojego zainteresowania także na autobiografie pisane przez zwykłych ludzi. Jest to podejście bardzo bliskie antropologowi, dla którego autobiografia jest ważna przede wszystkim jako ślad ludzkiej egzystencji - subiektywny zapis czyichś doświadczeń, czyjejś tożsamości i samoświadomości.

12 Zofia Mitosek wskazuje na pewien paradoks: „Według Lejeune’a, autobiografia mogłaby być wyjaśniona za pomocą kategorii »tożsamości narracyjnej«; z kolei według Ricoeura, kategorię tę można by dopracować w badaniach nad autobiografią. Czy jest to sławne koło hermeneutyczne, czy po prostu błędne koło - nie nam sądzić”. Z. Mitosek, Hermeneuta i autobiografia, „Teksty Drugie” 2002, nr 3, s. 138.

13 Ph. Lejeune, dz. cyt., s. 5.

${ }^{14}$ P. Ricouer, Time and Narrative, vol. 2, The University of Chicago Press, Chicago and London 1985, s. 93, za: K. Rosner, Narracja, tożsamość i czas, Towarzystwo Autorów i Wydawców Prac Naukowych UNIVERSITAS, Kraków 2003, s. 132.

${ }^{15}$ K. Rosner, dz. cyt., s. 125-136. 
definicją narracji sformułowaną przez francuskiego filozofa, uznając zarazem możliwość różnych (w tym nienarracyjnych albo nie w pełni narracyjnych) sposobów postrzegania świata (co nie wyklucza oczywiście wtórnej niejako narratywizacji tych doświadczeń, dokonującej się w ramach procesu opowiadania o sobie). Przyjmując tę tezę opieram się na ustaleniach badaczy zajmujących się funkcjonowaniem ludzi cierpiących na rozmaite zaburzenia neuropsychologiczne lub niepełnosprawnych. Ludzie ci wykazują niekiedy nadzwyczajne wprost możliwości poznawcze, a ich sposób odbioru rzeczywistości może znacząco odbiegać od utartych konwencji. Spektakularnymi tego przykładami są zarówno doświadczenia autystów, jak i - porywająco oraz ze znawstwem opisane przez Olivera Sacksa - przeżycia głuchoniemych ${ }^{16}$.

\section{Antropologiczne poszukiwanie i lektura narracji na temat autyzmu}

Współcześnie mamy do czynienia ze sporą liczbą opowieści (auto)biograficznych dotyczących doświadczenia autyzmu, co stwarza szerokie pole penetracji dla antropologa-narratywisty. Z uwagi na ograniczone ramy tego opracowania musiałam jednak dokonać wyboru materiału empirycznego. Wybór ten pozostaje oczywiście subiektywny i arbitralny, nie jest wszakże chaotyczny i przypadkowy. Dokonując go kierowałam się kilkoma istotnymi przesłankami. Po pierwsze, zależało mi na tym, aby badane teksty dobrze spełniały wymóg narracyjności, a więc aby tworzyły spójną, odpowiednio ustrukturowaną opowieść o życiu. Po drugie, sięgnęłam po relacje w pewien sposób typowe, wyrażające problemy i emocje wspólne dla wielu osób ze spektrum autyzmu. Po trzecie, zwróciłam się w stronę przekazów formułowanych przez dobrze funkcjonujących autystów, zdolnych do stworzenia nad wyraz wnikliwego studium własnej biografii, pozwalającego czytelnikowi niejako zobaczyć to zaburzenie „od środka”"17. Po czwarte wreszcie, wybrałam teksty, w których interesujące mnie wątki zostały wyraźnie i obszernie zarysowane.

Przyjęłam także określony tryb odbioru badanych opowieści, zgodny z wyznawanym przeze mnie paradygmatem antropologii narratywistycznej. Polegał on przede wszystkim na próbie intensywnej i skupionej lektury

16 O. Sacks, Zobaczyć głos. Podróż do świata ciszy, tłum. A. Małaczyński, Zysk i S-ka, Poznań 1998.

${ }_{17}$ Osoby gorzej radzące sobie w życiu, nie nawiązujące interakcji ze światem, upośledzone, mające problemy z mową komunikatywną czy z autodeskrypcją nie byłyby w stanie sprostać temu wyzwaniu. 
tych przekazów, w celu jak najgłębszego wniknięcia w - narracyjnie skonstruowany i wyrażony - świat życia ich autorów. Z każdą z omawianych relacji obcowałam zatem w sposób zaangażowany i długotrwały, wielokrotnie ponawiając proces lektury, powracając do szczególnie dla mnie ważnych partii i fragmentów tekstów. Dzięki temu udało mi się - jak sądzę - osiągnąć to, co wciąż jeszcze - pomimo dokonujących się współcześnie gruntownych przemian modelu etnograficznych badań terenowych - pozostaje dla nich konstytutywne, a mianowicie udało mi się nawiązać więź z moimi badanymi ${ }^{18}$. Oczywiście była i jest to więź niebezpośrednia, zmediatyzowana przez żywioł opowieści, zarazem jednak nacechowana i znacząca.

Przy okazji chcę również podkreślić, że mimo iż omawiane przeze mnie relacje oświetlają doświadczenia wspólne dla olbrzymiej rzeszy autystów (poczucie odmienności, nieprzystosowania, społecznej ekskluzji), bardzo istotny jest dla mnie ich wymiar indywidualny - to, że mówię w swoim opracowaniu o konkretnych ludziach, znanych mi z imienia i z nazwiska, żyjących w danym miejscu i czasie, przeżywających określone uczucia, wyzwania i trudności. Jest to zbieżne z moim antropologicznym credo, z moją wizją antropologii, dla której najważniejszy jest człowiek oraz spotkanie z nim, wsłuchanie/wczytanie się w jego głos - nie po to, rzecz jasna, aby go osądzić, wykorzystać, obnażyć lub nim kierować, lecz aby go poznać i spróbować zrozumieć.

I jeszcze jedna uwaga związana z antropologiczną eksploracją świata autystów. Jak już wyjaśniłam, świat ten przybliżam i opowiadam w swoim tekście poprzez skupioną lekturę ich opowieści, są one dla mnie głównym kluczem do jego bram, jednak moja znajomość tego świata ma również bardzo solidne oparcie w empirii, które wykorzystuję przy lekturze wybranych autonarracji oraz literatury fachowej dotyczącej tego zaburzenia. Jest to o tyle ważne, iż w przypadku autyzmu mamy do czynienia ze sferą inności, wobec której język jest czasami niewydolny, niewystarczający, bezradny, która nie daje się w całości i precyzyjnie upojęciowić, wyrazić w słowie. Pewne aspekty tego zaburzenia znam więc, odczuwam i rozumiem także za sprawą wiedzy obserwacyjnej - takiej, która z trudem poddaje się

${ }^{18}$ E. Kawiecka, Miejsce badań terenowych jako problem współczesnej antropologii społeczno-kulturowej, [w:] Fenomen genius loci. Tożsamość miejsca w kontekście historycznym i współczesnym, pod red. B. Gutowskiego, Muzeum Pałac w Wilanowie, Warszawa 2009, s. 94-96. 
translacji na struktury werbalne oraz formy narracyjne ${ }^{19}$. Owa nieredukowalna oraz nieprzekraczalna odmienność autystycznego przeżywania świata powoduje zarazem, iż jest ono nie w pełni dostępne poznawczo dla tak zwanej osoby neurotypowej ${ }^{20}$. Może ona - jak ja - uznawać empiryczną realność tych doświadczeń, ale nie jest w stanie do końca ich podzielać. Obcując z wieloma opowieściami autystów (i z nimi samymi) bardzo często miałam i mam poczucie efektu szklanych drzwi, poprzez które przeziera świat, który badam, ale które zdecydowanie odcinają mnie od tego świata ${ }^{21}$. Różnica sposobu percepcji okazuje się tu barierą nie do sforsowania. Dla przykładu: wiem o tym, że niektórzy autyści cierpią na perseweracje czy obronność dotykową, wielokrotnie miałam możliwość obserwowania tego rodzaju zachowań, ale nie potrafię zgłębić oraz przyswoić sobie ich esencji. Przymus powtarzania tej samej czynności lub odruchowa ucieczka przed dotykiem pozostają dla mnie zagadką, zdecydowanie wykraczają poza mój horyzont widzenia i odczuwania świata. Mimo tych ograniczeń nie rezygnuję z prób antropologicznego opisu i interpretacji autystycznego sposobu przeżywania rzeczywistości, kierując się przeświadczeniem, że każdy, nawet nie w pełni zadowalający i kompletny akt intelektualnego opanowania jakiegoś tematu jest lepszy niż kapitulacja, zaniechanie, milczenie. Aby jednak wyzwanie, jakie podjęłam, mogło się powieść, muszę - przynajmniej pokrótce i w terminach ogólnych - wytłumaczyć, czym jest autyzm.

\section{Autyzm - próba charakterystyki}

Autyzm (od greckiego słowa „autos”, co znaczy „sam”) stanowi całościowe zaburzenie rozwojowe ${ }^{22}$. Jako osobny zespół chorobowy został po raz

${ }^{19}$ Zdaję sobie sprawę, że - użyte przeze mnie - określenie „wiedza obserwacyjna” jest nie do końca fortunne i precyzyjne, bo przecież nie chodzi tu o beznamiętną, metodycznie prowadzoną obserwację, lecz o oparte na bliskości, pulsujące emocjami kontakty międzyludzkie, realizujące się w porządku codzienności, życia prywatnego. Tymczasem nie znajduję jednak lepszego terminu, który wyrażałby moje intencje i odczucia.

20 Określenia „neurotypowy” oraz „neuronietypowy” są dobrze zadomowione w dyskursie na temat zaburzeń neurologicznych, jednak używam ich z pewnym wahaniem. Wydają mi się one bowiem nieco stygmatyzujące.

${ }^{21}$ Metaforę drzwi oddzielających dwie rzeczywistości zaczerpnęłam od Temple Grandin. Taż, M. M. Scariano, Byłam dzieckiem autystycznym, tłum. E. Zachara, PWN, Warszawa -Wrocław 1995, s. 57-64.

${ }^{22}$ Piśmiennictwo naukowe oraz popularnonaukowe dotyczące spektrum zaburzeń autystycznych jest bardzo bogate, obejmuje zarówno teksty źródłowe, jak i prace przeglądowe. 
pierwszy scharakteryzowany w latach czterdziestych XX w. przez dwóch lekarzy psychiatrów - Leo Kannera i Hansa Aspergera. W literaturze specjalistycznej często podkreśla się, że autyzm ma wiele twarzy, zaburzenie to obejmuje bowiem rozległe spektrum przypadków o bardzo różnym stopniu głębokości i nasilenia objawów ${ }^{23}$. Najważniejsze, wymieniane w piśmiennictwie naukowym, cechy autystyczne to:

- postawa „od świata”, dążenie do izolacji, brak zainteresowania kontaktami społecznymi, osłabiona zdolność do nawiązywania interakcji społecznych;

- kłopoty z odczytywaniem wskazówek społecznych (wyrazu twarzy, mowy ciała, metafor, aluzji, ironii), tendencja do interpretowania zachowań i komunikatów społecznych dosłownie i wprost;

- przymus stałości i jednostajności otoczenia (w opinii specjalistów powtarzalność oraz porządek są tym, co nadaje obrazowi świata autystów spójną i stabilną strukturę, dlatego też osobom tym bardzo ciężko przychodzi adaptowanie się do nowości, każda najdrobniejsza zmiana w codziennych czynnościach, jak ubieranie się, czesanie, spożywanie posiłków, zabiegi higieniczne, organizacja dnia czy osobistej przestrzeni wytrąca ich z równowagi i silnie rozstraja);

- trudności w widzeniu spraw z perspektywy innej osoby (określane jako brak zdolności metalizowania, deficyt teorii umysłu);

W swoim opisie autyzmu sięgam do wielu opracowań. Wymienię najważniejsze: Autyzm. Kontrowersje i wyzwania, pod red. W. Dykcika, Wydawnictwo ERUDITUS, Poznań 1994; Autyzm wyzwaniem naszych czasów, pod red. T. Gałkowskiego i J. Kossewskiej, Wydawnictwo Naukowe Akademii Pedagogicznej, Kraków 2001; S. Baron-Cohen, H. Tager-Flusberg, Understanding other minds I. Perspectives from autism, Oxford University Press, Oxford 1993; S. Baron -Cohen, Mindblindness. An essay on autism and theory of mind, The MIT Press, Cambridge 1995; L. Bobkowicz-Lewartowska, Autyzm dziecięcy. Zagadnienia diagnozy i terapii, Oficyna Wydawnicza IMPULS, Kraków 2004; C. H. Delacato, Dziwne, niepojęte. Autystyczne dziecko, tłum. M. Główczak, Fundacja SYNAPSIS, Warszawa 1995; U. Frith, Autyzm i zespół Aspergera, tłum. B. Godlewska, Wydawnictwo Lekarskie PZWL, Warszawa 2005; Taż, Autyzm. Wyjaśnienie tajemnicy, tłum. M. Hernik, G. Krajewski, Gdańskie Wydawnictwo Psychologiczne, Gdańsk 2008; L. Jackson, Świry, dziwadła i zespół Aspergera. Przewodnik użytkownika dorastania, tłum. E. Niezgoda, Wydawnictwo Fraszka Edukacyjna we współpracy z Fundacją SYNAPSIS, Warszawa 2005; Ch. Preißman, Zespół Aspergera. Jak z nim żyć, jak pomagać, jak prowadzić terapię, tłum. J. Arentewicz, Gdańskie Wydawnictwo Psychologiczne, Sopot 2012.

${ }^{23}$ Funkcjonowanie osoby autystycznej w dużej mierze zależy od rodzaju tego zaburzenia. Na przykład pacjenci z autyzmem klasycznym - „typu Kannera” są zwykle opóźnieni w rozwoju, czasem nawet poważnie, „Aspergerowcy” zaś mają normalny albo podwyższony iloraz inteligencji. 
- czynności stereotypowe, repetytywne (może to być podskakiwanie, kołysanie się, ugniatanie części ciała, kręcenie palcami, obracanie w rękach lub podrzucanie przedmiotów; zachowania te mogą wynikać z potrzeby redukcji pobudzenia nadaktywego układu nerwowego koncentrując się na monotonnych, powtarzających się czynnościach autyści blokują niejako dopływ bodźców, które ich ranią i z którymi nie mogą sobie poradzić);

- utrudniona akwizycja języka, zaburzenia mowy (tendencja do pustosłowia, echolalia, wypowiedzi konstruowane wyłącznie z klisz) lub całkowity brak mowy;

- problemy w nawiązywaniu kontaktu wzrokowego, uciekające lub wędrujące spojrzenie;

- impulsywność oraz kłopoty z panowaniem nad emocjami, zwłaszcza w przytłaczającym i nieznanym sobie otoczeniu (ma to ścisły związek ze wzmiankowanym przeze mnie autystycznym przymusem stałości otoczenia);

- łatwość mechanicznego zapamiętywania;

- wąskie, silnie pochłaniające zainteresowania i uzdolnienia (zwane wysepkowymi - może to być na przykład szczególnie angażujące zainteresowanie dźwiękami, słowami, liczbami, datami lub symbolami), tego rodzaju fascynacje i fiksacje składają się niekiedy na tak zwany syndrom sawanta ${ }^{24}$;

- upośledzona koordynacja ruchowa;

${ }^{24}$ Wyraz „sawant” jest obecnie używany w miejsce dawniejszego określenia „idiota -sawant”. Stara terminologia została zarzucona ze względu na występujący w niej dyskryminujący i obraźliwy element „idiota”, ale do pewnego stopnia była trafna. Poprzez zestawienie dwóch określeń o przeciwnym znaczeniu (savant w języku angielskim oznacza erudytę) wyrażała ona bowiem typowy dla autyzmu fenomen polegający na tym, że osoby, do których to określenie odnoszono, osiągały imponujące wyniki na jednym polu, a jednocześnie bardzo słabo radziły sobie w innych obszarach. Literatura dotycząca autyzmu pełna jest opisów osób, które wykazywały szczególne uzdolnienia w zakresie tworzenia poezji, nauki języków obcych, muzykowania, rysowania, malowania, liczenia czy też pamięciowego określania dnia tygodnia dla dowolnie wybranej daty w kalendarzu, ale poza tym zupełnie nie potrafiły odnaleźć się w życiu codziennym, nie umiały o siebie zadbać oraz nie interesowały się niczym poza ulubioną tematyką. U. Frith, Autyzm. Wyjaśnienie..., s. 180-185. Źródłem wiedzy o syndromie sawanta są te między innymi prace: D. Draaisma, Dlaczego życie płynie szybciej, gdy się starzejemy. O pamięci autobiograficznej, tłum. E. Jusewicz-Kalter, PIW, Warszawa 2006, s. 91-121; 0. Sacks, Antropolog na Marsie, tłum. P. Amsterdamski, Wydawnictwo Zysk i S-ka, Poznań 2008, s. 235301; M. Scheerer, E. Rothmann, K. Goldstein, A case of „idiot savant”. An experimental study of personality organization, American Psychological Association, Evanston 1945; D. A. Treffert, Extraoridinary people. Understanding „idiot savants”, Harper and Row, New York 1989. 
- odmienne funkcjonowanie percepcyjne i sensoryczne (nadwrażliwość lub niewrażliwość na bodźce zmysłowe, synestezja, kłopoty z przerzutnością uwagi itp.).

Przytoczone cechy składają się na szerokie spektrum autyzmu, należy jednak pamiętać - podkreślę to po raz kolejny - że każdy przypadek tego zaburzenia jest trochę inny. Wynika to z tego, że każdy człowiek jest odrębną i niepowtarzalną całością biologiczną, a także podlega innym oddziaływaniom kulturowym i biograficznym, gromadzi odmienne doświadczenia, uczestniczy w różnych środowiskach społecznych, dysponuje sobie właściwą inteligencją, wrażliwością i wyobraźnią. Rodzaj oraz stopień natężenia poszczególnych objawów autyzmu mogą więc być rozmaite, mogą też one ewoluować w czasie, bo przecież autyści - jak i inni ludzie - nie są statyczni. Dodajmy także, że - jak dotąd - nie wyjaśniono szczegółowo etiologii tego schorzenia. Współcześnie najwięcej zwolenników ma hipoteza mówiąca, że kluczowe dla jego powstania są czynniki genetyczne. Oprócz nich jako ważne faktory ryzyka podaje się: wiek ojca powyżej czterdziestego roku życia, urazy okołoporodowe, uszkodzenia centralnego układu nerwowego oraz poważne infekcje i intensywne antybiotykoterapie w okresie niemowlęctwa.

W leczeniu autyzmu dominuje podejście niefarmakologiczne, oparte między innymi na terapii behawioralnej, specjalnej edukacji oraz diecie (substancje wykluczane z jadłospisu autystów to: gluten, glukoza i kazeina; na liście produktów „zakazanych” w tym schorzeniu znajdują się zaś: mleko, pszenica, kukurydza, pomidory, czekolada, cukier i grzyby). Cały czas opracowywane są coraz doskonalsze i skuteczniejsze metody terapeutyczne, jak również narzędzia służące do trafnego diagnozowania tej przypadłości. $\mathrm{Na}$ coraz szerszą skalę prowadzone są badania przesiewowe, które mają przyczyniać się do wczesnego wykrywania autyzmu wśród dziewczynek i chłopców, przy czym z danych statystycznych wynika, że problem ten o wiele częściej dotyczy płci męskiej. Szacuje się, że przeciętnie na piętnastu autystycznych chłopców przypada tylko jedna autystyczna dziewczynka. Za powód tej dysproporcji uznaje się zwykle pewne czynniki biologiczne (odmienna budowa mózgu, gospodarka hormonalna) oraz społeczno-kulturowe (przebieg ewolucji kulturowej, nieco inny sposób socjalizacji). Niezależnie jednak od płci pacjenta w terapii autyzmu przeważa dziś podejście holistyczne, to 
znaczy programem terapeutycznym obejmowane są całe rodziny, ponieważ problem doświadczany przez indywiduum nieuchronnie odciska się na innych członkach wspólnoty rodzinnej.

Aby możliwe było zrozumienie autyzmu, niezbędna jest fachowa wiedza z wielu dziedzin: medycyny, psychologii, pedagogiki, niektórych działów językoznawstwa, a także antropologii. Autyści to bowiem zbiorowość odmienna pod względem kulturowym: pod względem języka, emocji, codziennych praktyk, upodobań i zachowań. Zadaniem antropologa jest przeto uchwycić oraz opisać tę odmienność - wyjątkowość percepcji, świadomości, sposobu egzystencji i wewnętrznych przeżyć.

\section{Kilka słów o autorach badanych opowieści}

W artykule tym sięgam do narracji autobiograficznych dwóch osób Temple Grandin i Daniela Tammeta. Zasadniczą kanwą dla moich rozważań są ich autobiografie, zatytułowane Byłam dzieckiem autystycznym ${ }^{25}$ oraz Urodziłem się pewnego błękitnego dnia. Pamiętniki nadzwyczajnego umysłu z zespołem Aspergera ${ }^{26}$. Jak zaznaczyłam wcześniej, do lektury i interpretacji ich wypowiedzi wykorzystuję także wiedzę o autyzmie czerpaną z autopsji.

Temple Grandin i Daniel Tammet to osoby niezwykłe, obdarzone nieprzeciętną umysłowością, inteligencją oraz mające barwne, choć - co typowe dla autyzmu - nie zawsze szczęśliwe życie, zatrute przez doznanie izolacji, beznadziei oraz rozliczne słabości i ograniczenia, które trudno przełamać. Ich opowieści stanowią zatem splot tego, co powtarzalne w biografiach autystów: poczucia inności, nieprzystawalności do świata, braku akceptacji z tym, co na swój sposób wyjątkowe i co ich autorzy zawdzięczają zarówno pewnym szczęśliwym zbiegom okoliczności, wsparciu ze strony własnych środowisk, jak i osobistym zasobom (talentom, charyzmie, samozaparciu), które pozwoliły im na przezwyciężenie wielu autystycznych tendencji i osiągnięcie sukcesu. Na przykładzie ich losów widać też wyraźnie, że każdy przypadek autyzmu jest inny, a to, w jakim kierunku rozwinie się biografia takiej osoby jest zależne od wielu czynników, związanych zarówno z jej indywidualnymi cechami biopsychicznymi, jak i doświadczeniami społeczno-kulturowymi.

${ }_{25}$ T. Grandin, M. M. Scariano, dz. cyt.

${ }^{26}$ D. Tammet, Urodziłem się pewnego błękitnego dnia. Pamiętniki nadzwyczajnego umysłu z zespołem Aspergera, tłum. M. Mysiorska, Wydawnictwo Czarne, Wołowiec 2010. 
Dowiedzmy się zatem, kim są Temple Grandin i Daniel Tammet? Co wiemy o nich i o ich życiu ${ }^{27}$ ?

Temple Grandin urodziła się 29 sierpnia 1947 r. w Bostonie, w Stanach Zjednoczonych. Była najstarszym dzieckiem w rodzinie, ma troje rodzeństwa. Po ukończeniu college’u podjęła studia psychologiczne, ale wkrótce je porzuciła i zajęła się zgłębianiem tajników świata zwierząt. Pracę magisterską poświęciła zagadnieniu poskromów na farmach, a jej rozprawę uznano za przełomową i pionierską. Opublikowała serię artykułów o przytrzymywaniu zwierząt - zarówno w pismach fachowych, jak i branżowych gazetach reklamowych. Ta niezwykła autystka ma również doktorat Wydziału Nauk o Zwierzętach Uniwersytetu w Illinois. Zaprojektowała ponad jedną trzecią urządzeń do hodowli bydła w USA, a wiele jej projektów stosowane jest także w innych krajach. Obecnie pracuje jako profesor nauk o zwierzętach w Colorado State University. Od wielu lat udziela się jako konsultantka w sprawach dotyczących zachowania zwierząt. Skonstruowana przez nią słynna maszyna do uścisków - służąca do stymulacji dotykowej autystów - była wzorowana właśnie na poskromach dla bydła. Temple Grandin jest jedną z najbardziej znanych osób autystycznych w świecie, od wielu lat angażuje się w popularyzowanie wiedzy o tym schorzeniu. Prowadzi wykłady gościnne na ten temat oraz mówi o nim w programach telewizyjnych. Podjęta przez nią batalia z autyzmem budzi powszechny podziw i szacunek - z destrukcyjnego, nie umiejącego mówić i rzucającego ekskrementami dziecka T. Grandin przedzierzgnęła się bowiem w twórczą, niezależną i świadomą siebie kobietę, autorytet w dziedzinie badań naukowych, aktywistkę i pisarkę. Jej fascynujące życie stało się kanwą opowiadań oraz filmów ${ }^{28}$. Mieszka w Fort Collins, w Colorado.

Daniel Tammet urodził się 31 stycznia 1979 r. w Londynie, w Wielkiej Brytanii. Jest najstarszy z dziewięciorga rodzeństwa, ma trzech braci oraz pięć sióstr. Cierpi na łagodną odmianę autyzmu, określaną jako zespół Aspergera, a także na związane z tym zespołem zaburzenie zwane synestezją, które sprawia, że widzi kolory, kształty oraz faktury liter i liczb. Z tego powodu data jego urodzin jest dla niego niebieska, a cyfry, które ją tworzą,

27 Wiele informacji o sobie moi narratorzy zamieszczają na swoich stronach internetowych: www.templegrandin.com (ostatni dostęp: 11 maja 2013); www.danieltammet.net (ostatni dostęp: 11 maja 2013).

${ }^{28}$ T. Grandin jest między innymi bohaterką znanego opowiadania O. Sacksa pt. Antropolog na Marsie. Tenże, Antropolog ..., s. 302-364. 
kształtem przypominają mu otoczaki. Synestezję Daniela zapoczątkował prawdopodobnie przebyty przez niego $\mathrm{w}$ wieku czterech lat atak epilepsji. Wciąż nie wyjaśniono, co wywołuje epilepsję, ale wiadomo, że o wiele częściej występuje ona u osób ze spektrum zaburzeń autystycznych. Mniej więcej jedna trzecia dzieci z autyzmem przed okresem pokwitania zapada na tę przypadłość. Dlatego uważa się, że te dwie dysfunkcje mogą mieć wspólną przyczynę $\mathrm{w}$ budowie mózgu lub w leżących u jej podstaw uwarunkowaniach genetycznych.

Synestezyjne funkcjonowanie Daniela jest sprzężone z jego genialnymi zdolnościami liczbowymi oraz językowymi, które składają się na tak zwany syndrom sawanta. W swoich obliczeniach z łatwością prześciga kalkulator, a żeby sprawdzić, czy ma rację, potrzeba pomocy komputera. Dzięki nadzwyczajnym możliwościom poznawczym 14 marca 2004 r. D. Tammet ustanowił nowy rekord Wielkiej Brytanii i Europy w publicznej recytacji z pamięci liczby pi - podał 22514 jej cyfr bez błędów w czasie pięciu godzin i dziewięciu minut. Podobnie łatwo przychodzi mu nauka języków. W czasie spisywania pamiętnika znał ich dziesięć: angielski (swój język ojczysty), fiński, francuski, niemiecki, litewski, esperanto, hiszpański, rumuński, walijski oraz islandzki, który - w ramach eksperymentu badawczego - przyswoił sobie w ciągu zaledwie siedmiu dni. W 2008 r. D. Tammet wyemigrował do Francji, mieszka w Paryżu.

\section{Doświadczanie przestrzeni w autyzmie - na podstawie wybranych autonarracji}

Opozycja miasto-wieś konotuje dwa odrębne repertuary sensów i znaczeń, odnoszących się także do doświadczeń przestrzennych. Pierwszy człon opozycji wskazuje na takie między innymi cechy, jak: duża intensywność zabudowy i gęstość zaludnienia, zwiększona liczba środków komunikacji (zarówno indywidualnej, jak i zbiorowej), rozbudowana oraz intensywnie wykorzystywana sieć infrastruktury, hałas, wysokie tempo życia, a także ograniczony dostęp do świata natury. Wieś natomiast mieści w swym polu znaczeniowym takie treści, jak: oddalenie od wielkich skupisk ludzkich, rozproszony charakter zabudowy, spokój, cisza oraz bliski kontakt z przyrodą 29 .

${ }^{29}$ Zarysowana dychotomia ma z pewnością uproszczony i wysoce uogólniony charakter, mimo to przyjmuję ją na użytek swoich rozważań. 
Ben Singer w artykule „Sensacyjność” a świat wielkomiejskiej nowoczesności zwraca uwagę na to, że życie miejskie - ze swej istoty intensywniejsze niż życie na wsi - zyskało jeszcze na rozmachu wraz z nadejściem nowoczesności. Ulice metropolii zaczęła wówczas charakteryzować niespotykana do tej pory spektakularność, wynikająca z nagromadzenia na jednej przestrzeni olbrzymiej liczby ludzi, pojazdów i przedmiotów. Mieszkaniec miasta został tym samym narażony na audiowizualną, akustyczną, haptyczną oraz społeczną stymulację czy wręcz hiperstymulację. Oto jak B. Siger opisuje ową wyłaniającą się w procesie dziejowym monstrualność miejskiej przestrzeni:

Narodziny wielkomiejskiej nowoczesności były zjawiskiem wzbudzającym grozę.
Miastazawsze były pełne ruchu, ale nigdy ażtak, jak tuż przed przełomem stuleci. Fala
urbanizacji sprawiła, że miasta stały się znacznie bardziej zatłoczone, chaotyczne,
zróżnicowane społecznie, nasycone bodźcami bardziej, niż kiedykolwiek wcześnieje.

Epoka nowoczesna wywołała tym samym „przemoc sensoryczną”, stan permanentnego zagrożenia dla ludzkich zmysłów. Ciało i umysł mieszkańca wielkiego miasta zostały wystawione na działanie hiperbodźca, narażone na ciąg nieustannych wstrząsów spowodowanych przez zmulitplikowany chaos municypalnej przestrzeni - jej wielobarwność, prędkość, zgiełk itd. Podczas wędrówki przez nowoczesne miasto jej mieszkańcowi napinały się i prężyły wszystkie zmysły - jego otoczenie migotało tysiącem świateł; odurzało chmurą przeróżnych woni; spowijało warstwą kurzu, sadzy i spalin; ogłuszało wyciem klaksonów, hukiem, trzaskiem i chrzęstem; zakleszczało w nieprzebranym tłumie przechodniów, narażało na ich dotyk i fizyczną bliskość. Oczywiście nie brakowało miłośników tego nowego oblicza świata, dla których potężniejąca intensywność czy wręcz agresywność miejskiej ekumeny była źródłem zachwytu i ekscytacji. Jednostki bardziej wrażliwe czuły się jednak przytłoczone, ich delikatny układ nerwowy nie radził sobie z lawinowym napływem danych zmysłowych ${ }^{31}$.

${ }^{30}$ B. Singer, „Sensacyjnośc” a świat wielkomiejskiej nowoczesności, tłum. Ł. Biskupski, W. Marzec, J. Słodkowski, A. Zysiak, [w:] Rekonfiguracje modernizmu. Nowoczesność i kultura popularna, pod red. T. Majewskiego, Wydawnictwa Akademickie i Profesjonalne, Warszawa 2009, s. 143.

${ }^{31}$ M. Nieszczerzewska, Stymulacja autentyczna i inscenizowana. Dwa rodzaje sensorycznej intensywności miejskiego życia, [w:] Spektakle zmysłów, pod red. A. Wieczorkiewicz i M. Kostaszuk-Romanowskiej, Wydawnictwo IFiS PAN, Warszawa 2010, s. 261-277. 
Współcześnie mamy co prawda do czynienia z odrzuceniem licznych założeń modernistycznej urbanistyki, jednak miasto nadal pozostaje domeną ruchu, pędu i szoku dla zmysłów. Także i dzisiaj spora liczba jego mieszkańców nie radzi sobie z generowaną przezeń „przemocą sensoryczną”32. Do grona tego należy wielu autystów. Wynika to z charakterystycznego dla owego schorzenia odmiennego funkcjonowania zmysłowego i percepcyjnego, które wiąże się z obniżoną tolerancją na doznania sensoryczne ${ }^{33}$.

Szczególnie wymowna jest pod tym względem narracja Daniela Tammeta, w której przestrzeń miasta jawi się jako źródło rozlicznych cierpień dla autysty ${ }^{34}$. W swoim pamiętniku autor wspomina, że nieprzewidywalność oraz kakofonia miejskiego życia niemal od zawsze napełniały go lękiem. Od dziecka bał się głośno trąbiących samochodów oraz przebywania w zgiełku i tłumie ${ }^{35}$. Trudny do zniesienia był oraz jest dla niego zatem pobyt w miejscach takich, jak: autobus, trolejbus, ulica, kino czy restauracja ${ }^{36}$. Miejsca te, skolonizowane zwykle przez zbiorowiska ludzi, gwarne i chaotyczne, oddziałują bowiem drażniąco na psychikę i zmysły autysty: bezładna plątanina hałasu, zapachów i obrazów przytłacza go i frustruje, napływających zewsząd danych sensorycznych jest zbyt dużo, by móc je mentalnie ogarnąć i uporządkować. Konsekwencją tego jest pogorszenie indywidualnej percepcji i uwagi, człowiek z autyzmem zaczyna tracić kontakt z rzeczywistością, wyłącza się, a przy tym staje się niespokojny i nieprzystępny. Podobnie wpływa na Daniela Tammeta wizyta w supermarkecie ${ }^{37}$. Wielkość sklepu, liczba obsługi i kupujących, bogactwo asortymentu, a także sztuczne oświetlenie i wysoka temperatura wprawiają go w stan zmysło-

${ }^{32}$ Doświadczenia osób nadwrażliwych stały się przedmiotem interesujących i wnikliwych analiz Iwony Kabzińskiej. Taż, Jak pogodzić wodę z ogniem? Miłośnicy ciszy kontra wielbiciele hałasu, „Zabawy i Zabawki” 2009, nr 1-4, s. 75-99; Taż, Nadwrażliwi - marginalizowana mniejszość kulturowa, [w:] Ciekawość świata, ludzi, kultury... Księga jubileuszowa ofiarowana Profesorowi Ryszardowi Kantorowi z okazji czterdziestolecia pracy naukowej, pod red. R. Hołdy, T. Palecznego, Księgarnia Akademicka, Kraków 2012, s. 121-139.

${ }^{33}$ Możliwa jest też sytuacja odwrotna, a więc niewrażliwość na dane zmysłowe. Czasem bywa ona zresztą niebezpieczna, gdyż brak odczuwania bólu, zimna lub gorąca może doprowadzić człowieka do poważnych urazów oraz chorób somatycznych.

${ }^{34} \mathrm{Z}$ uwagi na ograniczone ramy tego opracowania rezygnuję z przytaczania cytatów pochodzących z badanych opowieści. O doświadczeniach D. Tammeta i T. Grandin opowiadam własnym głosem, scalając je w rodzaj antropologicznej meganarracji.

35 D. Tammet, dz. cyt., s. 43.

36 Tamże, s. 130, 148, 159, 193, 242.

37 Tamże, s. 266. 
wego splątania, przygniatają i męczą. Naturalną reakcją na ową przemoc ze strony miejskiej przestrzeni jest ucieczka czy też próba odseparowania od miejsc odbieranych jako opresyjne i wrogie - takich, które ranią. Autysta opracowuje zatem własną mentalną i emocjonalną mapę miejskiej ekumeny oraz spontanicznie zwraca się ku tym obszarom, w których dochodzi do rozrzedzenia i złagodzenia zmysłowej treści rzeczywistości, dzięki czemu jego czuła, nadwrażliwa psychika doświadcza stanu satysfakcji i uspokojenia. Wiedziony instynktem oraz traumatycznym wspomnieniem przeszłości zaczyna omijać miejskie wyspy zgiełku, znienawidzone przylądki tłoku, chaosu i zamętu oraz poszukiwać enklaw ciszy i porządku. Dla autora pamiętnika są nimi takie choćby miejsca, jak: park, ogród, muzeum, galeria czy biblioteka ${ }^{38}$. Tam właśnie ma szansę odpocząć od napierającej zewsząd cywilizacji, technologicznego i konsumpcyjnego pędu, zanurzyć się w kojącej fali spokoju. Zauważmy zarazem, że doświadczenia przestrzenne, jakie oferują te miejsca, są częstokroć semantycznie zbieżne z treściami ewokowanymi przez pojęcie wsi, wiążą się z przeżyciem ciszy, oddalenia od rozedrganych i ekspansywnych skupisk ludzkich, doznaniem bliskiego kontaktu z przyrodą ${ }^{39}$ oraz izolacją od monstrualności świata opartego na sztuczności, przemyśle i technologii. Szczególnie cenny jest dla autysty bezpośredni kontakt z przyrodą, stanowi on dla niego źródło najczystszej przyjemności zmysłowej, zarazem zaś odstresowuje go i rozładowuje skumulowane napięcie nerwowe. D. Tammet pisze, że obcowanie ze światem natury - słuchanie śpiewu ptaków, szumu drzew, oddychanie świeżym powietrzem, wystawianie się na ciepło słoneczne, a także studiowanie przez dotyk tworów przyrody, jak choćby kasztany czy kora drzew - wywierają na niego zbawienny ${ }_{\text {wpływ }}^{40}$. Dodajmy w tym miejscu, że charakterystyczną cechą autyzmu jest wzmożona koncentracja na szczegółach, uwielbienie detalu, stąd ludzie ci czują się częstokroć pochłonięci przez zjawiska fizyczne i przyrodnicze, których inni nie zauważają wcale lub tylko przelotnie. Odwołując się do znanej na gruncie nauk humanistycznych koncepcji można by rzec, iż osoby autystyczne obdarzone są często „okiem flâneura”, które zwraca baczną

38 Tamże, s. 242, 244, 265.

39 Przebywanie na łonie natury uspokaja autystów, ale zdarza się, że nie dostarcza im zupełnie żadnych wrażeń o charakterze estetycznym i emocjonalnym. Ze względu na odmienną pracę mózgu ludzie ci nie są w stanie odczuwać piękna przyrody, kontemplować jej monumentalności czy romantycznej malowniczości.

40 D. Tammet, dz. cyt., s. 82-83, 265. 
uwagę na drobiazgi, wyłuskuje je z tła i błyskawicznie rejestruje. Może to być chociażby widok przesypujących się ziarenek piasku, wirujących na wietrze płatków śniegu, cząsteczek kurzu albo światłocieni tworzących zmienne układy na ścianie budynku w miarę przemijania dnia ${ }^{41}$.

Analiza relacji Daniela Tammeta przekonuje, że otaczająca autystę oraz odbierana przez niego zmysłowo przestrzeń jest różnie postrzegana i wartościowana, rzadko kiedy jednak pozostaje całkowicie obojętna i nienacechowana. Pobyt w niej doprowadza zwykle do silnego spiętrzenia pozytywnych lub negatywnych uczuć: radości, zadowolenia albo frustracji i przykrości. Nawiązując do wyjściowej dychotomii miasto-wieś można stwierdzić, że środowisko miejskie za sprawą swej (nad)intensywności oraz spektakularności jest często charakteryzowane przez ludzi z autyzmem jako nieprzyjazne i wrogie. Hiperwrażliwy autysta dokonuje wyrazistej waloryzacji jego struktury przestrzennej, wyznacza własne ścieżki oraz sposoby jego eksploracji, zgodne ze swoimi potrzebami i reakcjami. Preferuje on przy tym przestrzenie wolne od „terroru sensorycznego", pełne ciszy i spokoju, zorganizowane w sposób logiczny i przewidywalny. Jego miejska egzystencja, lokalne wędrówki i peregrynacje toczą się przeto starannie wyselekcjonowanymi, a częstokroć także bocznymi szlakami, z ominięciem najruchliwszych punktów metropolii, masowo uczęszczanych miejsc, ulic czy arterii. Miasto autysty staje się przez to - metaforycznie rzecz ujmując - miastem zaułków, zakamarków i przesmyków, jego reaktywność sensoryczna i przestrzenna każe mu dowartościować peryferia i suburbia, a także obszary do pewnego stopnia izolowane, wypreparowane z wielkomiejskiego tła, nie skażone przez wszędobylski hałas i zgiełk, w których stymulacja zmysłowa jest mniej intensywna, ogranicza lub blokuje dopływ bolesnych i dezorientujących go impulsów.

Typowa dla autyzmu awersja do zmian decyduje zarazem o symbiotycznym niemalże stosunku autysty do miejsc uznawanych za dobrze znane i oswojone. Kontaktz obcą przestrzeniąjest dla niego zwykle silnie stresujący, a sposobem na rozplątanie urazowego węzła, który zaciska się w momencie zetknięcia się z nowym terytorium, jest wynalezienie rytuałów pomocnych w procesie zadomowienia się w tym środowisku. Ważne jest zatem, aby opracować stały i niezmienny program dnia, który uporządkuje chaos nowej rzeczywistości oraz znaleźć osoby pełniące wobec niego rolę prze-

41 Tamże, s. 35, 76, 79-80. 
wodników-opiekunów - takie, które oprowadzą autystę po okolicy; objaśnią, jak należy się w niej poruszać, wskażą punkty orientacyjne, kluczowe trasy, ścieżki oraz przejścia ${ }^{42}$.

W autobiograficznej opowieści Temple Grandin przestrzeń jest konceptualizowana i waloryzowana w dość podobny sposób, również i ta autorka bardzo często wspomina o silnym przywiązaniu do miejsc dobrze jej znanych $^{43}$ oraz o swej nadwrażliwości na treści zmysłowe. Najgorsze są dla niej doświadczenia ekspozycji na wiele różnych bodźców, rejestrowanych przez rozmaite kanały sensoryczne - natłok wielu głosów, skumulowane zapachy, ludzie krążący wokół, poruszający się w różnym tempie i w różnych kierunkach, nieustanny rwetes i zamieszanie, ciągłe dotykanie doprowadzają ją do stanów paniki i histerii ${ }^{44}$. Przebywanie oraz radzenie sobie w niektórych miejscach tworzących tkankę współczesnego miasta jest dla niej w związku z tym nie lada wyzwaniem. Przykładem jest pobyt na lotnisku, który wymaga jednoczesnego odbierania licznych bodźców i działania. Dla autysty to istna męka. T. Grandin nauczyła się wprawdzie „blokować” na szum tego miejsca i czytać, ale niemal niemożliwe jest dla niej odizolowanie się od hałasów portu lotniczego i rozmawianie przez telefon ${ }^{45}$.

Równie peszącym i bolesnym przeżyciem bywa dla osoby autystycznej uczęszczanie do szkoły-molocha, w której klasy liczą po trzydziestuczterdziestu uczniów, a każdego przedmiotu uczy inny nauczyciel. Człowiek zautyzmem czuje sięw takim środowisku beznadziejniezagubiony-zewsząd otacza go ruchliwy, hałaśliwy tłum, a tempo zmian jest zbyt zawrotne, by za nim nadążyć ${ }^{46}$. Ratunkiem dla nadmiernie pobudzonego układu nerwowego bywa ucieczka w autystyczne fiksacje albo desperackie oscylowanie pomiędzy impulsywnym zachowaniem a wycofywaniem się w swój wewnętrzny świat, gdzie można uniknąć stymulacji. T. Grandin dodaje też, że swego czasu próbowała nie brać udziału w wycieczkach szkolnych, gdyż wzmagały jej niepokój ${ }^{47}$. Najbardziej zbawienne jest jednak unikanie dużych szkół oraz nauka w małych, spokojnych placówkach. Autobiografka pisze, że gdyby znalazła się na olbrzymim uniwersytecie, zagubiłaby się z pewnością

\footnotetext{
${ }^{42}$ Tamże, s. 156-157.

43 T. Grandin, M. M. Scariano, dz. cyt., s. 90.

${ }_{44}$ Tamże, s. 21.

45 Tamże, s. 20.

46 Tamże, s. 45.

47 Tamże, s. 56.
} 
w gęstym labiryncie korytarzy, sal i budynków, między tysiącami studentów. Szczęśliwym trafem wybrano dla niej niewielką uczelnię ${ }^{48}$.

Dookolną przestrzeń autorka wiąże jednak nie tylko z przeżyciami nadmiernej stymulacji i przeciążenia sensorycznego. To dla niej również domena niezwykłych olśnień i przełomów biograficznych, prowokujących do rozbudowanych ciągów introspekcji i autotematycznych rozważań. Takim doświadczeniem była dla niej chociażby pamiętna wizyta w wesołym miasteczku. Jednym z urządzeń był w tej świątyni rozrywki rotor - duża beczka, w której ludzie stoją pod ścianami, a całość szybko kręci się w kółko. Siła odśrodkowa przyciska ich do ścian nawet wtedy, gdy podłoga opada w dół. T. Grandin z początku bała się tego urządzenia. Spłoszona patrzyła, jak koleżanki z klasy próbują przejażdżki, w końcu jednak uległa ich namowom i na trzęsących się nogach wsiadła do beczki. Serce podeszło jej do gardła, a ciarki przebiegły po plecach, gdy silnik ryknął i rotor rozpoczął swój gorączkowy, szaleńczy taniec. Na narratorkę spłynął ulewny deszcz doznań zmysłowych. Kolory niebieskiego nieba, białych chmur i złotego słońca zmieszały się wirując. Zapachy cukrowej waty, prażonej kukurydzy i tacos kręciły się w koło, każdy z osobna, aż w końcu i one połączyły się w jedną zaskakującą spiralę woni. Uczepiona ścian rotora autobiografka w napięciu czekała, aż opadnie podłoga. Wreszcie ze skrzypieniem zawiasów podłoga zapadła się, ukazując ziemię poniżej, ale - co niezwykłe - teraz jej zmysły były tak przepełnione różnymi bodźcami, że nie czuła strachu ani zdenerwowania. Tylko rozluźnienie i błogość. Po tej przejażdżce uspokoiła się po raz pierwszy od bardzo dawna. Zachęcona reakcją własnego organizmu pojechała rotorem jeszcze raz - i jeszcze, i jeszcze, kontemplując najpierw nadmierne pobudzenie zmysłów, aż do wartości ekstremalnej, a później przyjemne rozładowanie nagromadzonego napięcia i relaks ${ }^{49}$. W taki oto sposób T. Grandin odkryła remedium na własne słabości. Cóż jednak począć, jeśli przebywa się z dala od uciech i rozrywek miejskiego życia, na przykład na rancho lub na biwaku, gdzie nie ma wesołego miasteczka i jazd rotorem? W takich sytuacjach pomocny dla osoby autystycznej okazuje się wzmożony wysiłek fizyczny, jazda konna, jazda na nartach, pływanie, wędkowanie

${ }^{48}$ Tamże, s. 77.

${ }^{49}$ Badania wykazują, że autyści z początku boją się gwałtownych ruchów, lecz później nierzadko fiksują się na nie. Dowiedziono też, że jeśli u dziecka nie występuje żadna forma epilepsji, kręcenie się wpływa korzystnie na błędnik, odpowiedzialny za zmysł równowagi i koordynację ruchów. 
i intensywna praca fizyczna. Co więcej, przestrzeń podmiejska oferuje kontakt z przyrodą - dostępność łąk, jezior, strumieni, gór oraz obecność zwierząt, co też miewa dobry wpływ na autystę ${ }^{50}$. Dla Temple Grandin zwierzęta, zwłaszcza hodowlane, są bardzo ważne - więź z nimi określiła całe jej dorosłe życie. Dlatego tak lubiane są przez nią miejsca, w których one przebywają - rancha, farmy, zagrody, rzeźnie, poskromy itp ${ }^{51}$. Nieodmiennie za nimi tęskni i nie znosi się z nimi rozstawaćs2.

Na zakończenie omówię jeszcze jeden epizod, który okazał się punktem zwrotnym w życiu Temple Grandin, a którego areną stało się jedno z najbardziej typowych miejsc na mapie współczesnego miasta, czyli supermarket. W swojej opowieści autorka podaje, że gdy przeniosła się na studia do Arizony, dopadła ją fiksacja na punkcie rozsuwanych automatycznie drzwi supermarketu. Korzystanie z takich drzwi jest całkowicie legalne i z reguły bezproblemowe, używają ich tysiące klientów, jednak ona długo nie mogła przezwyciężyć lęku przed tą konstrukcją. Gdy tylko przed nimi stanęła, czuła się fizycznie chora. Drżały jej nogi, czoło wilgotniało od potu, a żołądek boleśnie się kurczył. Przebiegała przez nie w nadziei, że zostawi te irytujące objawy za sobą, ale one ścigały ją nieubłaganie i oplatały niczym trujący bluszcz. Kiedyś, gdy była już po drugiej stronie, musiała oprzeć się o ścianę i odpocząć - serce łopotało jej w piersi jak oszalałe, całe ciało dygotało, pojawiły się mdłości. Zaczęła rozmyślać, czy by nie rozbić tych drzwi i nie pozbyć się ich na zawsze. Próbowała też racjonalizować tę fiksację. Pytała samą siebie, co ją przeraża w zwykłych rozsuwanych szklanych drzwiach martwym, bezrozumnym i pozbawionym woli przedmiocie? Po trzech tygodniach zmagań z obsesją w końcu przeszła przez nie jak zwyczajna klientka, swobodnie i bez pośpiechu. Było to dla niej nader budujące doświadczenie. W ciągu następnych kilku tygodni często odwiedzała supermarket. Pewnego dnia przeszła przez drzwi tam i z powrotem aż dziesięć razy. Obawiała się tylko śmieszności. Kierownik sklepu zauważył ją, ale na szczęście okazał się wyrozumiały i nic nie powiedział ${ }^{53}$. Epizod ten okazał się dla

${ }^{50}$ T. Grandin, M. M. Scariano, dz. cyt., s. 50-51, 56, 67, 94.

${ }^{51}$ Miłość do zwierząt, szacunek dla nich oraz troska o nie, a jednocześnie udział w ich zabijaniu są dla wielu osób nie do pogodzenia. T. Grandin próbuje wyjaśnić tę pozorną z jej punktu widzenia dwoistość postawy wskazując, że zabijanie jest wprawdzie okrutne, ale jest integralną częścią natury. Nie da się uciec od faktu, że zwierzęta hodowlane muszą umrzeć. Ważne jednak, by zapewnić im możliwie bezbolesną i szybką śmierć. Tamże, s. 98.

52 Tamże, s. 96.

53 Tamże, s. 89. 
T. Grandin swoistym przełomem poznawczym i biograficznym. Za pomocą własnych nasilonych doświadczeń zmysłowych oraz nawiązującego do nich wizualnego symbolu szklanych drzwi odkryła bowiem paralelę pomiędzy współżyciem z ludźmi a przekraczaniem fizycznej granicy w przestrzeni ${ }^{54}$. Zrozumiała, że do drzwi należy się zbliżać powoli i nie robić nic na siłę; w przeciwnym razie można je rozbić, uderzyć się lub poturbować. Związki z ludźmi są podobnej natury. Jeśli robi się coś desperacko i na siłę, wzajemna więź jest zagrożona. Jeden gwałtowny ruch może wszystko zniszczyć. Jedno złe słowo lub niezdarny gest mogą zrujnować miesiącami budowane miłość, przyjaźń, zaufanie i szacunek. Dla osoby autystycznej to doniosłe odkrycie ${ }^{55}$.

Z przedstawionych rozważań wynika, że otaczająca przestrzeń zarówno miejska, jak i wiejska stanowią scenę intensywnych przeżyć dla ludzi z autyzmem. Przeżycia te obejmują rozmaite wymiary rzeczywistości i egzystencji, wiążą się ze sferą zmysłów, emocji oraz intelektualnych sądów, odkryć i iluminacji.

Uzyskując wgląd w opowieści autystów nieodmiennie dowiadujemy się czegoś ważnego o ich wewnętrznym świecie - opowieści te odsłaniają bowiem tematykę, strukturę i swoisty koloryt ich doświadczeń; z niezwykłą wyrazistością pokazują to, w czym mieści się przeszłość, teraźniejszość i przyszłość tych ludzi; niejednokrotnie wyrażają ich treści intymne, ukrywane przed innymi, a nawet przed sobą samym. Opowieści te są zatem jak błysk latarni, przerzucenie mostu do krainy autyzmu - krainy niezwykłej i intrygującej, a pod wieloma względami wciąż nieodkrytej i dziewiczej. Tym bardziej więc nie można ustawać w wysiłku jej poznania i opisania, także w języku współczesnej humanistyki i antropologii.

\section{Zakończenie}

Tekst mój stanowi osobisty rekonesans na polu problematyki związanej z funkcjonowaniem osób autystycznych oraz cierpiących na schorzenia pokrewne. Niezbędne są oczywiście dalsze pogłębione oraz systematyczne studia i analizy na ten temat (również w zakresie doświadczeń przestrzennych, bo przecież doświadczenia te mogą się różnić u różnych osób). Mam nadzieję, że owe prace będą prowadzone i że przyczynią się do lepszego

${ }^{54}$ Symbol drzwi pojawia się u narratorki wielokrotnie, zawsze sugerując transgresję, zmianę, przekroczenie dotychczasowej kondycji oraz przejście do innego sposobu bycia w świecie.

55 T. Grandin, M. M. Scariano, dz. cyt., s. 88-89, 92. 
zrozumienia zjawiska autyzmu. Jak bowiem słusznie zauważył Antoni Kępiński, do poznania zaburzeń o charakterze psychicznym oraz neurologicznym (autyzm należy do tej drugiej grupy) konieczna jest współpraca specjalistów z różnych dziedzin: lekarzy, znawców historii i teorii języka, historii kultury, etnologii, antropologii itp. ${ }^{56}$ Poszerzanie takiej wiedzy jest niezbędne ze względów medycznych - po to, aby można było skutecznie leczyć pacjentów zmagających się z tymi przypadłościami, ale i społecznych - gdyż pomaga to w lepszej aktywizacji tych osób, przeciwdziała ich stygmatyzowaniu i wykluczaniu poza nawias zbiorowości, pozwala im żyć w sposób godny i twórczy, realizować marzenia i zyskiwać szacunek. Na nas, ludziach zdrowych, spoczywa zaś moralny obowiązek wspierania tych, których dotknęła choroba oraz pamięci o tym, że z medycznego punktu widzenia choroba jest czymś szkodliwym; często prowadzi do degradacji i osłabienia życiowego potencjału jednostki, jednak z perspektywy historii i wartości kulturowych bywa ona bogactwem, poszerza bowiem naszą wiedzę o obszary, których przyszłoby zapewne żałować, gdyby je wykreślić z dziejów ludzkości. W bardzo piękny i przejmujący sposób wyraził to A. Kępiński: „Tak jak obraz uzyskuje pełnię dzięki światłom i cieniom, kontrastom i walorom, tak pełnia życia człowieka i jego poznanie są możliwe dzięki najbardziej krańcowym doznaniom, nawet za cenę cierpienia (pathos) jako patologicznego przekroczenia określonej granicy zwanej zdrowiem (...)"

\section{BIBLIOGRAFIA}

- Autyzm. Kontrowersje i wyzwania, pod red. W. Dykcika, Wydawnictwo ERUDITUS, Poznań 1994.

- Autyzm wyzwaniem naszych czasów, pod red. T. Gałkowskiego i J. Kossewskiej, Wydawnictwo Naukowe Akademii Pedagogicznej, Kraków 2001.

- Baron-Cohen S., Mindblindness. An essay on autism and theory of mind, The MIT Press, Cambridge 1995.

- Baron-Cohen S., Tager-Flusberg H., Understanding other minds I. Perspectives from autism, Oxford University Press, Oxford 1993.

- Bobkowicz-Lewartowska L., Autyzm dziecięcy. Zagadnienia diagnozy i terapii, Oficyna Wydawnicza IMPULS, Kraków 2004.

\footnotetext{
${ }^{56}$ A. Kępiński, Schizofrenia, Wydawnictwo Literackie, Kraków 2001, s. 78.

57 Tamże, s. 79-80.
} 
- Delacato C. H., Dziwne, niepojęte. Autystyczne dziecko, tłum. M. Główczak, Fundacja SYNAPSIS, Warszawa 1995.

- Draaisma D., Dlaczego życie płynie szybciej, gdy się starzejemy. O pamięci autobiograficznej, tłum. E. Jusewicz-Kalter, PIW, Warszawa 2006.

- Frith U., Autyzm. Wyjaśnienie tajemnicy, tłum. M. Hernik, G. Krajewski, Gdańskie Wydawnictwo Psychologiczne, Gdańsk 2008.

- Frith U., Autyzm i zespół Aspergera, tłum. B. Godlewska, Wydawnictwo Lekarskie PZWL, Warszawa 2005.

- Grandin T., Scariano M. M., Byłam dzieckiem autystycznym, tłum. E. Zachara, PWN, Warszawa-Wrocław 1995.

- Jackson L., Świry, dziwadła i zespół Aspergera. Przewodnik użytkownika dorastania, tłum. E. Niezgoda, Wydawnictwo Fraszka Edukacyjna we współpracy z Fundacją SYNAPSIS, Warszawa 2005.

- Kabzińska I., Jak pogodzić wodę z ogniem? Miłośnicy ciszy kontra wielbiciele hałasu, „Zabawy i Zabawki” 2009, nr 1-4.

- Kabzińska I., Nadwrażliwi - marginalizowana mniejszość kulturowa, [w:] Ciekawość świata, ludzi, kultury... Księga jubileuszowa ofiarowana Profesorowi Ryszardowi Kantorowi z okazji czterdziestolecia pracy naukowej, pod red. R. Hołdy, T. Palecznego, Księgarnia Akademicka, Kraków 2012.

- Kawiecka E., Miejsce badań terenowych jako problem współczesnejantropologii społeczno-kulturowej, [w:] Fenomen genius loci. Tożsamość miejsca w kontekście historycznym i współczesnym, pod red. B. Gutowskiego, Muzeum Pałac w Wilanowie, Warszawa 2009.

- Kępiński A., Schizofrenia, Wydawnictwo Literackie, Kraków 2001.

- Lejeune Ph., Wariacje na temat pewnego paktu. O autobiografii, tłum. W. Grajewski, S. Jaworski, A. Labuda, R. Lubas-Bartoszyńska, Towarzystwo Autorów i Wydawców Prac Naukowych UNIVERSITAS, Kraków 2001.

- Mitosek Z., Hermeneuta i autobiografia, „Teksty Drugie” 2002, nr 3.

- Nieszczerzewska M., Stymulacja autentyczna i inscenizowana. Dwa rodzaje sensorycznej intensywności miejskiego życia, [w:] Spektakle zmysłów, pod red. A. Wieczorkiewicz i Moniki Kostaszuk-Romanowskiej, Wydawnictwo IFiS PAN, Warszawa 2010.

- Preißman Ch., Zespół Aspergera. Jak z nim żyć, jak pomagać, jak prowadzić terapię, tłum. J. Arentewicz, Gdańskie Wydawnictwo Psychologiczne, Sopot 2012.

- Ricoeur P., Czas i opowieść. Konfiguracja w opowieści fikcyjnej, t. 2, tłum. J. Jakubowski, Wydawnictwo Uniwersytetu Jagiellońskiego, Kraków 2008.

- Ricouer P., Time and Narrative, vol. 2, The University of Chicago Press, Chicago -London 1985.

- Rodak P., Wstęp. Autobiografia i dziennik osobisty jako przedmiot badań Philippe'a Lejeune'a, [w:] Ph. Lejeune, „Drogi zeszycie...”, „drogi ekranie...”. O dziennikach osobistych, tłum. A. Karpowicz, M. i P. Rodakowie, Wydawnictwo Uniwersytetu Warszawskiego, Warszawa 2010. 
- Rosner K., Narracja, tożsamość i czas, Towarzystwo Autorów i Wydawców Prac Naukowych UNIVERSITAS, Kraków 2003.

- Sacks O., Antropolog na Marsie, tłum. P. Amsterdamski, Wydawnictwo Zysk i S-ka, Poznań 2008.

- Sacks O., Zobaczyć głos. Podróż do świata ciszy, tłum. A. Małaczyński, Zysk i S-ka, Poznań 1998.

- Scheerer M., Rothmann E., Goldstein K., A case of „,idiot savant”. An experimental study of personality organization, American Psychological Association, Evanston 1945.

- Singer B., „Sensacyjność” a świat wielkomiejskiej nowoczesności, tłum. Ł. Biskupski, W. Marzec, J. Słodkowski, A. Zysiak, [w:] Rekonfiguracje modernizmu. Nowoczesność i kultura popularna, pod red. T. Majewskiego, Wydawnictwa Akademickie i Profesjonalne, Warszawa 2009.

- Treffert D. A., Extraoridinary people. Understanding „idiot savants”, Harper and Row, New York 1989.

- Tammet D., Urodziłem się pewnego błękitnego dnia. Pamiętniki nadzwyczajnego umysłu z zespołem Aspergera, tłum. M. Mysiorska, Wydawnictwo Czarne, Wołowiec 2010.

- www.danieltammet.net (dostęp: 11.05.2013).

- www.templegrandin.com (dostęp: 11.05.2013).

\section{IN TOWN AND COUNTRY. EXPERIENCING SPACE IN AUTISM \\ - ANTHROPOLOGICAL RECONNAISSANCE}

Autism spectrum disorders is a range of complex neurodevelopment disorders, characterized by impaired social imagination and interactions, communication difficulties, sensory integration problems, and restrictive, repetitive, and stereotyped behaviours. The spectrum is probably conditioned by genes and includes different forms of autism - the most severe of them is classical autism, one of milder forms is known as Asperger syndrome. It is proved that autism occurs in all ethnic and socioeconomic groups and affects every age group. Experts estimate that males are more likely to have the spectrum of disorders than females. The tendency depends on sociocultural as well on biological factors.

Present article is based on written narratives of two individuals with well functioning autism - Temple Grandin and Daniel Tammet. On a theoretical level it is inspired by works of two outstanding French scholars - Paul Ricoeur and Philippe Lejeune. Both of them claim that narrative is a fundamental structure which allows us to organize, to express and to understand our biographical experiences. The authoress of the text reflects how two mentioned autistic individuals experience a space - various environments and surroundings. That kind of biographical experiences is very specific and peculiar in autism, especially because of autistic sensory problems. 